At-Turats

Jurnal Pemikiran Pendidikan Islam

journal homepage: http://jurnaliainpontianak.or.id/index.php/atturats

\title{
MORFOLOGI GENDER DALAM BAHASA ARAB DAN INGGRIS (ANALISIS KONTRASTIF DALAM FUNGSI PENGAJARAN BAHASA ARAB)
}

\author{
Ardiansyah \\ Fakultas Syariah dan Ekonomi Islam (FSEI) \\ Institut Agama Islam Negeri (IAIN) Pontianak \\ ardiansera@gmail.com
}

\begin{abstract}
A B S T R A C T
This research purposes is to explain gender mark lingual units whether in Arabic or English on morphology level addressed to language pronounciation. Contrastive analysis results can be used to understand Arabic gender by making english as language connections. The data taken from relevant dictionaries because it is one of written language container. The data proceed using three stages : data supply, data analysis and data analysis results supply. On analysis stage: this research using contrastive methods. This research conclusion that both languages have more diffences than similarities. Arabic has dominated by bound morpheme while English has dominated by free morpheme or lexical.
\end{abstract}

Key words: Gender, Arabic, English, Contrastive.

\section{PENDAHULUAN}

Setiap manusia yang dilahirkan ke dunia terbagi menjadi dua jenis yaitu lakilaki dan perempuan. Perbedaan biologis ini mempunyai kesesuaian di samping bahwa perempuan mempunyai rahim, menyusui, sel telur dan, sedangkan laki-laki mempunyai jenggot dan kumis, perbedaan tersebut bersifat given dan kodrati sehingga melahirkan peran yang sifatnya kodrati pula. Hal ini senada dengan firman Allah SWT :

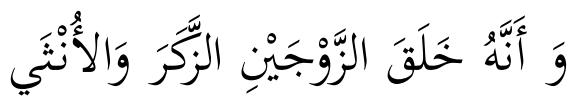

\footnotetext{
${ }^{1}$ Q.S. an-Najm (53): 45
}

Dan Dia-lah yang menciptakan berpasangpasangan laki-laki dan perempuan. ${ }^{1}$

Penelitian gender, dewasa ini dipenuhi dengan intrik persamaan derajat antara laki-laki dan perempuan. Dalam penelitian gender, para ilmuwan banyak memfokuskan dalam penelitian yang berbau teologis dan kultural sehingga penelitian gender dari sisi kebahasaan memerlukan perhatian lebih.

Anwar dalam tesisnya yang berjudul Penanda Gender dalam Perspektif Bahasa dan Budaya, menyebutkan bahwa bahasa Arab (selanjutnya disingkat dengan bA) merupakan salah satu penyebab marjinalisasi dan diskriminasi hak-hak 
perempuan. Hal ini dilatar belakangi oleh hasil penelitiannya yang menyatakan bahwa bA mempunyai tata bahasa yang patriakhi. ${ }^{2}$ Tentu hal ini diperkuat dengan adanya teori yang mengatakan bahwa bahasa merupakan cerminan budaya.

Keberadaan bA tentu sangat penting, tidak hanya menjadi alat komunikasi di Timur Tengah (baca: Arab), akan tetapi juga menjadi bahasa agama Islam sehingga bA merupakan bahasa standar dalam pembentukan norma-norma agama. ${ }^{3}$ Begitu juga dengan bahasa Inggris (selanjutnya disingkat dengan bI) yang kini menjadi bahasa Internasional dan juga merupakan alat komunikasi bangsa Barat. Dalam hal ini bahasa Inggris merupakan cerminan dari kultur bangsa Barat yang menjadi tolak ukur dalam praktik persamaan gender oleh negara ketiga.

\section{METODELOGI PENELITIAN}

Penelitian ini ditulis berdasarkan rumusan masalah yang nantinya akan menjadi arah penulisan artikel ini, yaitu (1) bagaimana bentuk satuan lingual penanda gender bA dan bI pada level morfologis khususnya pada sasaran pronomina?, (2) Apa saja persamaan dan perbedaan satuan penanda gender tersebut?

Adapun penelitian ini bertujuan untuk (1) menjelaskan bentuk satuan lingual penanda gender bA dan bI pada tataran morfem dengan sasaran pronomina, dan (2) mendeskripsikan persamaan dan perbedaan satuan lingual.

Penelitian ini menggunakan beberapa teori dalam menganalisis data, diantaranya adalah:

2 Miftakhulkhairah Anwar. Penanda Gender dalam Perspektif Bahasa dan Budaya. Yogyakarta: Tesis UGM, 2004, hlm. 1. Pernyataan ini berdasarkan hasil analisis beliau dalam memperbanding bahasa Arab dan bahasa Indonesia.

${ }^{3}$ Keberadaan bahasa Arab dipergunakan untuk berbagai keperluan agama, seperti menafsirkan ayat-ayat al-Qur'an, ibadah, bahkan menjadi pemersatu umat Islam di seluruh dunia.

\section{Analisis Kontrastif}

Harimurti Kridalaksana mendefinisikan analisis kontrastif dengan metode sinkronis dalam analisis bahasa untuk menunjukkan persamaan dan perbedaan antara bahasa-bahasa atau dialek-dialek untuk mencari prinsip yang dapat diterapkan dalam masalah praktis, seperti pengajaran dan penerjemahan. ${ }^{4}$

Sesuai dengan akar katanya "to contras" yang berarti membandingkan ${ }^{5}$, analisis kontrastif bertugas membadingkan dua hal baik persamaannya maupun perbedaannya supaya kedua hal tersebut menjadi jelas.

\section{Morfologi}

Penelitian ini mengetengahkan perbandingan linguistik mikro dengan kata lain analisis yang dilakukan adalah analisis kontrastif mikrolinguistik yang memperhatikan subsistem bahasa seperti fonologi, morfologi, dan sintaksis.

Morfologi berasal dari bI "morphology" yang berarti ilmu tentang morfem. J.W.M. Verhaar yang merupakan salah satu linguis modern mendefinisikan morfologi dengan cabang linguistik yang mengidentifikasikan satuan-satuan dasar bahasa sebagai satuan lingual. ${ }^{6}$

Sebelum penelitian ini dilakukan, peneliti terlebih dahulu telah melihat beberapa penelitian bahasa sebelumnya yang memperhatikan permasalahan gender. Diantaranya adalah Penanda Gender dalam Perspektif Bahasa dan Budaya karya Miftahulkhairah Anwar pada tahun 2004. Penelitian ini adalah sebuah tesis yang diajukan Anwar yang mengkaji permasalahan gender dalam bA dan bahasa Indonesia. Perbedaan dengan penelitian ini

4 Harimurti Kridalaksana. Kamus Linguistik. Linguistik. Jakarta: Gramedia Pustaka Utama, 2008. Pada entri "Analisis Kontrastif".

5 Martin H Manser. Oxford Learner's Pocket Dictionary. New York: Oxford University Press, cetakan kelima, 1995. Pada entri "contras"

${ }^{6}$ J.W.M. Verhaar. Asas-asas Linguistik. Yogyakarta: UGM Press, 2001. Hlm. 97 
adalah penelitian ini mengkaji permasalahan gender antara bahasa Arab dan bahasa Inggris dengan level yang lebih sempit yaitu hanya pada level morfologis. Penelitian kedua ialah Buku Grammar and Gender karya Dennis Barron menarik suatu referensi tentang konstruksi perbedaan jenis kelamin pada sistem grammar bahasa Inggris, atau dengan kata lain, melihat bagaimana perbedaan jenis kelamin antara laki-laki dan perempuan ditempatkan oleh grammar. Data yang dikumpulkan Baron dalam penelitiannya ini diambil dari karya sastra.

Penelitian ini menggunakan tiga tahapan strategi prosedural, yakni:

1. Tahap Penyediaan Data

Pada tahap ini, data diperoleh dengan metode simak yakni menyimak penggunaan penandaan gender pada tataran morfologi. Kemudian dilanjutkan dengan teknik catat yaitu mencatat data-data objek penelitian dari ragam tulis, seperti kamus, surat kabar, tabloid, majalah, karya sastra, buku, dsb. Dalam hal ini, data bA diambil dari kamus al-Munjid karya Louis Ma'luf dan didukung oleh sumber lainnya, sedangkan data bI diambil dari Kamus Inggris-Indonesia Karya John M.Echols dan Hassan Shadily. Kemudian data-data tersebut diklasifikasi sesuai dengan jenis pronominanya.

\section{Tahap Analisis Data}

Dalam metode kontrastif, ada dua tahapan yang harus dilalui yaitu, tahap penjabaran dan tahap perbandingan. Dalam metode ini bA dijabarkan terlebih dahulu kemudian baru dijabarkan bI. Kemudian diperbandingkan penanda gender masingmasing bahasa tersebut pada tataran morfemnya.

\section{Tahap Penyediaan Hasil Analisis Data}

Pada tahap ini peneliti akan menggunakan metode penyajian informal

\footnotetext{
7 Sudaryanto. Metode Linguistik. Yogyakarta: UGM Press, 1986. Hlm. 4
}

dan metode formal, yaitu penyajian informal adalah metode penyajian hasil analisis data dengan menggunakan katakata, sedangkan metode formal adalah metode perumusan dengan menggunakan tanda atau lambang. ${ }^{7}$

\section{GENDER DAN SEX DALAM DIKOTOMI LEKSIKAL}

Ambiguitas bahasa merupakan salah satu penyebab terjadinya kesalahan dalam memaknai kata. Salah satunya ialah kata gender dan sex. Kata gender (gender) dalam bahasa Inggris, sulit untuk dicarikan padanan kata dalam bahasa Indonesia. Gender diartikan dengan perbedaan dalam tingkah laku yang tampak pada laki-laki dan perempuan. Sebagai contoh, laki-laki di kenal dengan gender kuat, perkasa, jantan, keras sedangkan perempuan dikenal dengan sifatnya lembah lembut, cantik, lemah. Sedangkan sex jika diterjemahkan ke dalam bahasa Indonesia ialah jenis kelamin. Sex berhubungan dengan anatomi tubuh manusia, seperti anatomi organ reproduksi, hormon, dan zat kimia.

Studi gender berkaitan dengan aspek budaya, perilaku, psikologis dan aspekaspek non biologis lainnya, sedangkan studi sex ditekankan pada aspek persoalan reproduksi dan aktivitas seksual. Dalam hal ini senada dengan definisi Women's Study Encyclopedia yang mengatakan gender adalah konsep kultural yang berupaya membuat perbedaan (dictinction) dalam hal peran, posisi, perilaku, mentalitas dan karakter emosional. $^{8}$

\section{GENDER DALAM BAHASA ARAB DAN BAHASA INGGRIS}

Munculnya gender dalam bahasa tidak terlepas dari keadaan realitas (dunia nyata) yang mencerminkan adanya jenis kelamin yang dilengkapi dengan atribut perilaku yang melekat kepadanya. Dalam studi

8 Siti Muslikhati. Feminisme dan Pemberdayaan Perempuan dalam Timbangan Islam. Jakarta: Gema Insani Press, 2004, hlm. 19-20. 
linguistik, gender digunakan untuk memisahkan kategori-kategori gramatika yang penggunaannya berkenaan dengan realitas kebahasaan.

1. Bahasa Arab

Dalam bA, permasalahan gender merupakan bagian dari persoalan nomina (isim). Gender dikategorikan menjadi dua bagian, yaitu mudzakkar dan mu'annas. Mudzakkar ialah isim yang menunjukkan arti laki-laki dari manusia atau hewan sedangkan mu'annas ialah isim yang menunjukkan arti perempuan atau yang dianggap perempuan pada manusia atau hewan. 9 Dalam bA, pembedaan maskulinitas dan feminimitas tidak hanya terjadi pada manusia atau makhluk hidup lainnya, akan tetapi juga mencakup bendabenda mati seperti pintu, meja, papan tulis dan lainnya. ${ }^{10}$

Penandaan feminim berdasarkan asumsi bahwa pada dasarnya semua kata dalam bA bentuk dasarnya adalah maskulin. Maka dari itu maskulin tidak memerlukan penanda khusus. Sebaliknya feminim haruslah mempunyai penanda khusus untuk membedakannya dengan maskulin Adapun penanda feminis adalah sebagai berikut:

a. ta marbūtah atau tā ta 'nis ; Merupakan morfem terikat berupa sufiks \{-at\} dengan alomortnya $\{-a h\}$. Morfem ini biasanya di ikuti oleh penanda kasus \{un\} untuk nominatif atau marfu', $\{$-an $\}$ untuk akusatif atau maftuh dan $\{-$ in $\}$ untuk kasus nominantif dan akusatif atau dalam keadaan majrur,

b. alif mamdūdah, berupa morfem terikat $\{-\bar{a}\}$. Morfem ini biasanya di ikuti penanda kasus $\{-\mathrm{u}\}$ untuk kasus

9 Fuad Ni'mah. Mulakhoṣ Qawāidu alLugah al-'Arabiyah. Beirut: Dār aś-Ṡaqāfah alIslāmiyah, hlm. 14. Fuad mengkategorikan pembagian gender ini kedalam ilmu saraf.

${ }^{10} \mathrm{Hal}$ ini bukan berarti benda mati tersebut mempunyai kelamin atau anatomi tubuh lainnya, akan tetapi sebagai klasifikasi maskulinitas dan feminitas berdasarkan penanda bahasa.

${ }^{11}$ Ibrahim Anis. at-Ta'nīs fi al-Lugah al'Arabiyyah. Kairo: Dār aț-Tibā'ah wa an-Nasyr wa at-Tauz̄ī', 1988, hlm. 105-150. nominatif, $\{-\mathrm{a}\}$ untuk kasus akusatif dan penanda $\{-i\}$ untuk kasus selain nominatif dan akusatif, dan

c. alif maqsūrah, berupa sufiks $\{-\mathrm{a}\}$. Morfem ini tidak mengalami perubahan baik itu di posisi $\mathrm{S}, \mathrm{P}$ atau $\mathrm{O} .{ }^{11}$

Hubungan dengan penanda gender, Mustafa al-Ghulayani membagi masingmasing jenis maskulin dan feminim dalam bentuk haqīqi dan majāzì. Bentuk feminim majazi dibagi lagi menjadi dua kategori yaitu majāzī lafaż dan majāzì lafaż dan ma'na. ${ }^{12}$

2. Bahasa Inggris

Jika bA membagi gender menjadi dua kelompok, hal ini berbeda dengan bI yang membagi gender menjadi empat kelompok $^{13}$, yaitu:

a. Masculine Gender ; yakni kata benda yang memiliki jenis kelamin laki-laki. Contoh : Father 'ayah', man 'pria', dan uncle 'paman',

b. Feminime Gender; yakni kata benda yang memiliki jenis kelamin perempuan. Contoh : mother 'ibu', wife 'istri', dan lady 'gadis',

c. Common Gender; yakni kata benda yang dapat berjenis kelamin laki-laki atau perempuan atau berjenis kelamin umum. Contoh teacher 'guru', parent 'orang tua', dan deer 'rusa',

d. Neuther Gender; yakni kata benda yang tidak mengenal jenis kelamin, baik itu sebagai Masculine Gender atau Feminime Gender. Contoh, book 'buku', gold 'emas', street 'jalan', money 'uang', happiness 'kesenangan', dan freedom 'kebebasan'.

\footnotetext{
${ }^{12}$ Mustafa Ghulayani. Jāmi 'u ad-Durūs al'Arabiyah, Semarang: asy-Syifa, 1992, hlm. 186187.

13 Rudi Haryono. ABC Plus English Grammar. Surabaya, Gitamedia Press, 2008, hlm. 15. Pembagian gender ini dikategorikan dalam kategori noun dalam gramatika bahasa Inggris yang di mana noun merupakan bagian dari part of speech.
} 


\section{PERBEDAAN GENDER DALAM BAHASA ARAB DAN BAHASA INGGRIS}

Secara umum, perbedaan antara bA dan bI sudah terlihat dari pembagian jenis gender. BA membagi gender menjadi 2 kelompok yaitu mudzakkar dan mu'annas yang kemudian dibagi lagi menjadi satuan yang lebih kecil sedangkan bI membagi gender atas 4 yaitu Masculin Gender, Feminime Gender, Common Gender dan Netrum Gender, untuk lebih jelasnya lihat tabel dibawah ini.

Tabel 1

Perbedaan Pembagian Gender

Bahasa Arab dan Bahasa Inggris

\begin{tabular}{|c|c|c|c|}
\hline \multicolumn{3}{|c|}{$\begin{array}{c}\text { Bahasa } \\
\text { Arab }\end{array}$} & $\begin{array}{l}\text { Bahasa } \\
\text { Inggris }\end{array}$ \\
\hline \multirow{2}{*}{$\begin{array}{l}\text { Mudzakkar } \\
\text { (maskulin) }\end{array}$} & Haqūq $\bar{\imath}$ & & \multirow{3}{*}{$\begin{array}{c}\text { Masculine } \\
\text { Gender }\end{array}$} \\
\hline & Majazī & & \\
\hline \multirow{3}{*}{$\begin{array}{l}\text { Mu'annas } \\
\text { (Feminim) }\end{array}$} & Haqūq $\bar{\imath}$ & & \\
\hline & \multirow[b]{2}{*}{ Majazì } & $\begin{array}{l}\text { Majazī } \\
\text { Lafazh }\end{array}$ & \multirow[t]{2}{*}{$\begin{array}{c}\text { Feminime } \\
\text { Gender }\end{array}$} \\
\hline & & $\begin{array}{c}\text { Majaz̄̄ } \\
\text { lafazh dan } \\
\text { ma'na }\end{array}$ & \\
\hline & & & $\begin{array}{c}\text { Common } \\
\text { Gender }\end{array}$ \\
\hline & & & $\begin{array}{l}\text { Neuther } \\
\text { Gender }\end{array}$ \\
\hline
\end{tabular}

Berdasarkan data yang dianalisis perbedaan gender pada tataran morfem dalam pronomina, ditemukan beberapa pronomina yang terpengaruhi atas perubahan gender itu, yaitu dalam bA pronomina persona, pronomina demonstrativa dan pronomina relativa, sedangkan dalam bI pronomina persona, pronomina posesiva dan pronomina refleksif.

1. Perbedaan pada Pronomina Persona

Pronomina persona atau kata ganti diri adalah kata yang menggantikan nama, baik bemyawa maupun tidak bernyawa. Kata ganti ini dapat dibedakan menjadi tiga golongan, yaitu kata ganti diri pertama, kedua, dan ketiga.

a. Perbedaan pada Pronomina Persona

Pertama

Kedua bahasa mempunyai pronomina persona pertama. Dalam bA pronomina persona pertama berupa morfem bebas dan morfem terikat, sedangkan dalam bI pronomina persona hanya berupa morfem bebas. Pada tataran gender, bahasa Inggris tidak memilah antara keduanya baik pada morfem bebas maupun terikat.

Tabel 2

Perbedaan pada Pronomina Persona Pertama

\begin{tabular}{|c|c|c|c|c|c|}
\hline \multicolumn{6}{|c|}{ Bahasa Arab } \\
\hline & & & & Tunggal & Jamak \\
\hline \multirow{2}{*}{ Bebas } & Subyek & & & $A n \bar{a}$ & Nahnu \\
\hline & Obyek & & & Iyyāyā & Iyyānāa \\
\hline \multirow{4}{*}{ Terikat } & \multirow{2}{*}{ Subyek } & Past & Sufiks & $\{-t u\}$ & $\{-n \bar{a}\}$ \\
\hline & & Present & Prefiks & $\{a-\}$ & $\{\mathrm{n}-\}$ \\
\hline & \multirow[t]{2}{*}{ Obyek } & & & & \\
\hline & & & Sufiks & $\{-n \bar{\imath}\}$ & $\{-n \bar{a}\}$ \\
\hline
\end{tabular}

\begin{tabular}{|c|c|}
\hline \multicolumn{2}{|c|}{ Bahasa Inggris } \\
\hline Tunggal & Jamak \\
\hline$I$ & $W e$ \\
\hline$M e$ & $U s$ \\
\hline
\end{tabular}

b. Pronomina Persona Kedua

Perbedaan di antara keduanya adalah pronomina persona kedua dalam bA mengenal bentuk morfem bebas dan terikat sedangkan bI hanya mengenal morfem bebas. Untuk lebih jelasnya lihat tabel berikut .

Dalam hal jumlah, pronomina persona kedua dalam bA terdapat dual sedangkan dalam bI tidak ditemukan. Dari jenis gender, bA memiliki jenis yang lebih kompleks yaitu mempunyai jenis maskulin, feminim dan netrum sedangkan bI hanya memiliki jenis netrum 
Tabel 3

Perbedaan pada Pronomina Persona Kedua

\begin{tabular}{|c|c|c|c|c|c|c|c|c|c|c|}
\hline & \multicolumn{8}{|c|}{ Bahasa Arab } & \multicolumn{2}{|c|}{ Bahasa Inggris } \\
\hline & & & & \multicolumn{2}{|c|}{ Tunggal } & Dual & \multicolumn{2}{|c|}{ Jamak } & Tungge & Jamak \\
\hline & & & & Maskulin & Feminim & Netrum & Maskulin & Feminim & Netr & \\
\hline \multirow{2}{*}{$\begin{array}{l}\text { a } \\
\text { Dे } \\
0\end{array}$} & 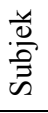 & & & $\{A n t a\}$ & $\{A n t i\}$ & $\{$ Antum $\bar{a}\}$ & $\{$ Antum $\}$ & $\{$ Antunna $\}$ & You & You \\
\hline & $\frac{\frac{y}{0}}{\frac{0}{0}}$ & & & $\{I y y a \bar{k} a\}$ & $\{I y y a \bar{a} k i\}$ & $\{$ Iyyakumā $\}$ & $\{$ Iyyākum $\}$ & $\{$ Iyyākunna $\}$ & You & You \\
\hline \multirow{6}{*}{ 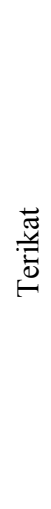 } & \multirow{5}{*}{ 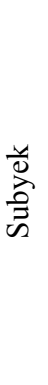 } & $\begin{array}{c}\vec{w} \\
\tilde{a}\end{array}$ & $\begin{array}{l}\text { 岸 } \\
\text { D. }\end{array}$ & $\{-t a\}$ & $\{-t i\}$ & $\{-t u m \bar{a}\}$ & $\{-$ tum $\}$ & $\{-$ tunna $\}$ & & \\
\hline & & \multirow{2}{*}{$\begin{array}{l}\overrightarrow{\overrightarrow{0}} \\
\dot{D} \\
\text { D. }\end{array}$} & \multirow{2}{*}{ 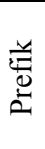 } & $\{a-\}$ & $\{t-\}$ & $\{t-\}$ & $\{t-\}$ & $\{t-\}$ & & \\
\hline & & & & & $\{-i n a\}$ & $\{-a n i\}$ & $\{-u n a\}$ & $\{-n a\}$ & & \\
\hline & & \multirow{2}{*}{ 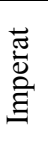 } & \multirow{2}{*}{$\begin{array}{l}\frac{y}{D} \\
\text { D }\end{array}$} & $\{u-\}$ & $\{u-\}$ & $\{u-\}$ & $\{u-\}$ & $\{u-\}$ & & \\
\hline & & & & & $\{-\mathrm{i}\}$ & $\{-\mathrm{a}\}$ & $\{-\overline{\mathrm{u}}\}$ & $\{-$ na $\}$ & & \\
\hline & $\frac{\frac{\pi}{0}}{\frac{0}{0}}$ & & 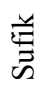 & $\{-k a\}$ & $\{-k i\}$ & $\{-k u m \bar{a}\}$ & $\{-k u m\}$ & $\{-k u n n a\}$ & & \\
\hline
\end{tabular}

c. Pronomina Persona Ketiga

Pada bentuk morfem, pronomina persona ketiga dalam bA terdiri dari bentuk morfem bebas dan morfem terikat dan mempunyai kongruensi pada verbnya. Sedangkan dalam pronomina persona ketiga dalam bI hanya mengenal morfem bebas.
Dalam hal jumlah, bA mempunyai bentuk yang komplek yaitu mempunyai bentuk tunggal, dual, dan jamak sedangkan dalam bI tidak menggu-nakan bentuk dual. Pada predikat gender, bA memiliki dua bentuk yaitu maskulin dan feminim, sedangkan bI lebih lengkap yaitu bentuk, maskulin, feminism dan netrum. Pada pema-kaiannya, pronominal persona ketiga bepengaruh pada kongruensi verb sedangkan dalam bI tidak terpengaruh. 
Tabel 4

Perbedaan pada Pronomina Persona Ketiga

\begin{tabular}{|c|c|c|c|c|c|c|c|c|c|c|c|c|c|}
\hline & \multicolumn{9}{|c|}{ Bahasa Arab } & \multicolumn{4}{|c|}{ Bahasa Inggris } \\
\hline & & & & \multicolumn{3}{|c|}{ Maskulin } & \multicolumn{3}{|c|}{ Feminim } & \multirow{2}{*}{$\begin{array}{c}\text { Maskulin } \\
\text { Tunggal }\end{array}$} & \multirow{2}{*}{\begin{tabular}{|l} 
Feminim \\
Tunggal
\end{tabular}} & \multicolumn{2}{|c|}{ Netrum } \\
\hline & & & & Tunggal & Dual & Jamak & Tunggal & Dual & Jamak & & & Tunggal & Jamak \\
\hline \multirow{2}{*}{$\begin{array}{l}\text { है } \\
\text { Dే } \\
\text { ص }\end{array}$} & $\begin{array}{l}\frac{y}{0} \\
\frac{\vec{D}}{0} \\
\text { की }\end{array}$ & & & $\{H u w a\}$ & $\{H u m \bar{a}\}$ & $\{\mathrm{Hum}\}$ & $\{$ Hiya $\}$ & $\{H u m \bar{a}\}$ & $\{$ Hunna $\}$ & $\{H e\}$ & $\{$ She $\}$ & $\{I t\}$ & $\{$ They $\}$ \\
\hline & $\frac{\frac{y}{0}}{0}$ & & & $\begin{array}{l}\{I y y \bar{a}- \\
h u\}\end{array}$ & $\begin{array}{l}\{\text { Iyyā- } \\
\text { humā }\}\end{array}$ & $\begin{array}{l}\{\text { Iyya }- \\
\text { hum }\}\end{array}$ & $\begin{array}{l}\{\text { Iyyā- } \\
\text { kum }\}\end{array}$ & $\begin{array}{l}\{\text { Iyya } \overline{-} \\
\text { humāa }\}\end{array}$ & $\begin{array}{c}\{\text { Iyyā- } \\
\text { hunna }\}\end{array}$ & $\{\mathrm{Him}\}$ & $\{H e r\}$ & $\{I t\}$ & $\{$ Them $\}$ \\
\hline \multirow{4}{*}{ 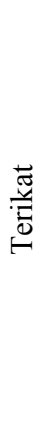 } & \multirow{3}{*}{ 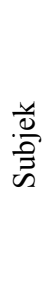 } & $\tilde{\widehat{\sigma}}^{0}$ & $\begin{array}{l}\frac{y}{0} \\
0 \\
0\end{array}$ & & $\{-a\}$ & $\{-u\}$ & $\{-t\}$ & $\{-t a\}$ & $\{-n a\}$ & - & - & - & - \\
\hline & & \multirow{2}{*}{ 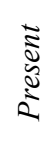 } & \multirow{2}{*}{ 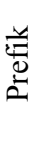 } & $\{y-\}$ & $\{y-\}$ & $\{y-\}$ & $\{t-\}$ & $\{t-\}$ & $\{y-\}$ & - & - & - & - \\
\hline & & & & & $\{-\bar{a} n i\}$ & $\{-\bar{u} n a\}$ & $\{-\bar{i} n a\}$ & $\{-\bar{a} n i\}$ & $\{-n a\}$ & - & - & - & - \\
\hline & $\frac{\frac{\pi}{0}}{\frac{0}{0}}$ & & $\begin{array}{l}\mathscr{y} \\
\vec{E} \\
\ddot{E}\end{array}$ & $\{-h u\}$ & $\{-h u m \bar{a}\}$ & $\{-h u m\}$ & $\{-h \bar{a}\}$ & $\{-h u m \bar{a}\}$ & $\{-h u n n\}$ & - & - & - & - \\
\hline
\end{tabular}

2. Perbedaan pada Pronomina Demonstrativa

Pronomina demonstrativa atau kata ganti penunjuk adalah kata ganti yang dapat menggantikan nama, keadaan, dan suatu peristiwa atau perbuatan. Perbedaan gender antara bA dan bI pada tataran ini terdapat pronomina demonstrativa umum (PDU), yaitu: "ini" dan "itu".
Perbedaan pronomina demonstrativa pada bA dan bI ialah pada bagian jumlah dan predikat gender. Pada jumlah, pronominal demostrativa pada bA menggunakan bentuk tunggal, dual, dan jamak sedangkan pada bI menggunakan bentuk tunggal dan jamak. Dalam hal predikat gender, bA menggunakan tiga jenis yaitu maskulin, feminim, dan netrum sedangkan bI menggunakan jenis netrum.

Tabel 5

Perbedaan pada Pronomina Demostrativa

\begin{tabular}{|c|c|c|c|}
\hline \multicolumn{2}{|c|}{ BA } & & BI \\
\hline PDU & Jumlah / Gender & PDU & Tunggal / netral \\
\hline$H \bar{a} d z \bar{a}$ & Tunggal / maskulin & This & Jamak / netral \\
\hline$H \bar{a} d z \bar{a} n i$ & Dual / maskulin & These & Tunggal/ netral \\
\hline$H \bar{a} d z i h i$ & Tunggal / feminin & This & Jamak / netral \\
\hline$H \bar{a} t \bar{a} n i$ & Dual / feminin & These & Jamak / netral \\
\hline Hāulāi & Jamak / netral & These & \\
\hline
\end{tabular}




\begin{tabular}{|c|c|c|c|}
\hline \multicolumn{2}{|c|}{ BA } & \multicolumn{2}{|c|}{ BI } \\
\hline Dzälika & Tunggal / maskulin & That & Tunggal / netral \\
\hline Dzānika & Dual / maskulin & Those & Jamak / netral \\
\hline Tilka & Tunggal / feminin & That & Tunggal / netral \\
\hline Tānika & Dual / feminin & Those & Jamak / netral \\
\hline Ulāika & Jamak / netral & Those & Jamak / netral \\
\hline
\end{tabular}

3. Perbedaan pada Pronomina Relativa

Pronomina relativa atau kata sambung adalah pronomina yang berfungsi sebagai penghubung dan menunjuk kembali pada kata yang mendahuluinya. Perbedaan pronomina relativa pada kedua bahasa tidak hanya berbeda dalam jumlah dan gender, akan tetapi juga terdapat perbedaan pada kedudukan dan penggunaannya.

Perbedaan kedua bahasa terdapat pada gender, jumlah, dan obyek yang menjadi pengganti. Dalam hal jumlah pronomina relativa $b A$ mengenal bentuk tunggal, dual dan jamak, sedangkan dalam bI hanya mengenal bentuk tunggal dan jamak. Dalam hal gender juga terdapat perbedaan, yaitu pronomina relativa bA mengenal bentuk gender maskulin dan feminim sedangkan bI hanya berbentuk netral.

Pada penggunaan pronomina yaitu pada obyeknya, pronomina relativa bA semuanya digunakan untuk mengganti orang dan benda mati, sedangkan pada bI tidak demikian. Misalnya pronomina who 'yang' dan whom 'yang' hanya digunakan untuk mengganti orang sedangkan pronomina which 'yang' digunakan untuk mengganti benda mati.

Tabel 6

Perbedaan pada Pronomina Relativa

\begin{tabular}{|c|c|c|c|c|c|c|c|}
\hline \multirow{4}{*}{ 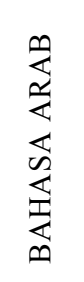 } & PR & Allādzi & Allādzāni & Allādzīna & Allatī & Allatāni & Allātī \\
\hline & Gender & Maskulin & Maskulin & Maskulin & Feminim & Feminim & Feminim \\
\hline & Jumlah & Tunggal & Dual & Jamak & Tunggal & Dual & Jamak \\
\hline & Obyek & $\begin{array}{c}\text { Orang/ } \\
\text { benda mati }\end{array}$ & $\begin{array}{c}\text { Orang/ } \\
\text { benda mati }\end{array}$ & $\begin{array}{c}\text { Orang/ } \\
\text { benda mati }\end{array}$ & $\begin{array}{c}\text { Orang/ } \\
\text { benda mati }\end{array}$ & $\begin{array}{c}\text { Orang/ } \\
\text { benda mati }\end{array}$ & $\begin{array}{l}\text { Orang/ } \\
\text { benda mati }\end{array}$ \\
\hline \multirow{4}{*}{ 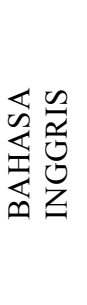 } & PR & Who & Whom & Whose & Which & What & That \\
\hline & Gender & Netral & Netral & Netral & Netral & Netral & Netral \\
\hline & Jumlah & $\begin{array}{l}\text { Tunggal } \\
\text { /jamak }\end{array}$ & $\begin{array}{l}\text { Tunggal } \\
\text { /jamak }\end{array}$ & $\begin{array}{c}\text { Tunggal } \\
\text { /jamak }\end{array}$ & $\begin{array}{l}\text { Tunggal } \\
\text { /jamak }\end{array}$ & Tunggal & $\begin{array}{l}\text { Tunggal } \\
\text { /jamak }\end{array}$ \\
\hline & Obyek & Orang & Orang & $\begin{array}{c}\text { Orang/ } \\
\text { benda mati }\end{array}$ & Benda mati & $\begin{array}{c}\text { Orang/ } \\
\text { benda mati }\end{array}$ & $\begin{array}{c}\text { Orang/ } \\
\text { benda mati }\end{array}$ \\
\hline
\end{tabular}

4. Perbedaan pada Pronomina Posesiva

Dalam gramatika $\mathrm{bA}$, pronomina posesiva mirip dengan pronomina persona terutama dalam penggunaan. Perbedaan pronomina posesiva kedua bahasa tidak hanya pada gender dan jumlah akan tetapi juga terdapat perbedaan pada bentuk morfem. Pronomina posesiva pada bA merupakan morfem terikat sedangkan pada bI menggunakan bentuk morfem bebas. 
Tabel 7

Perbedaan pada Pronomina Posesiva

\begin{tabular}{|c|c|c|c|c|c|c|c|}
\hline \multicolumn{3}{|c|}{ BAHASA ARAB } & \multirow[b]{2}{*}{ Glos } & \multicolumn{3}{|c|}{ BAHASA INGGRIS } & \multirow{2}{*}{ Glos } \\
\hline PP & Gender & Jumlah & & PP & Gender & Jumlah & \\
\hline$\{-\vec{u}\}$ & Netral & Tunggal & Punya saya & Mine & Netral & Tunggal & Punya Saya \\
\hline$\{-n \bar{a}\}$ & Netral & Jamak & Punya kita & Ours & Netral & Jamak & Punya kita \\
\hline$\{-k a\}$ & Maskulin & Tunggal & Punya kamu lk & Yours & Netral & Tunggal & $\begin{array}{l}\text { Punya } \\
\text { kamu }\end{array}$ \\
\hline$\{-k i\}$ & Feminim & Tunggal & Punya kamu pr & Yours & Netral & Tunggal & $\begin{array}{l}\text { Punya } \\
\text { kamu }\end{array}$ \\
\hline$\{-k u m \bar{a}\}$ & Netral & Dual & Punya kamu 2 lk/pr & - & - & - & - \\
\hline$\{-k u m\}$ & Makulin & Jamak & Punya kalian lk & Yours & Netral & Jamak & $\begin{array}{l}\text { Punya } \\
\text { kalian }\end{array}$ \\
\hline$(-h u\}$ & Maskulin & Tunggal & Punya dia $1 \mathrm{k}$ & His & Maskulin & Tunggal & $\begin{array}{c}\text { Punya dia } \\
\text { lk }\end{array}$ \\
\hline$\{-h \bar{a}\}$ & Feminim & Tunggal & Punya dia pr & hers & Feminim & Tunggal & $\begin{array}{l}\text { Punya dia } \\
\text { pr }\end{array}$ \\
\hline- & - & - & & Its & Netral & Tunggal & $\begin{array}{l}\text { Punya dia } \\
\text { (selain } \\
\text { manusia) }\end{array}$ \\
\hline$\{-h u m \bar{a}\}$ & Netral & Dual & Punya dia $2 \mathrm{lk} / \mathrm{pr}$ & - & - & - & - \\
\hline$\{-$ hum $\}$ & Maskulin & Tunggal & Punya mereka lk & Theirs & Netral & Jamak & $\begin{array}{l}\text { Punya } \\
\text { mereka }\end{array}$ \\
\hline$\{-$ hunna $\}$ & Feminim & Jamak & Punya mereka pr & Theirs & Netral & Jamak & $\begin{array}{l}\text { Punya } \\
\text { mereka }\end{array}$ \\
\hline
\end{tabular}

Dalam hal gender bA menggunakan bentuk feminim dan maskulin pada semua pronomina pose-sivanya baik itu pada jumlah tunggal, dual maupun jamak, sedangkan pada bI hanya menggunakan bentuk gender mas-kulin dan feminim hanya pada bentuk tunggal. Perbedaan lainnya terlihat pada bentuk jumlah, pada pronomina bA, penggunaan bentuk jumlah terdiri dari bentuk tunggal, dual dan jamak, sedang-kan dalam bI hanya menggunakan bentuk tunggal dan jamak. Sedangkan dari sisi lain terlihat perbedaan pada jumlah pronomina, dalam bA pronomina posesiva berjumlah 11 buah pronomina sedangkan bI berjumlah 8 buah pronomina.
5. Perbedaan pada Pronomina Refleksif

Dalam bA, pronomina refleksif terdiri dari dua morfem yaitu moferm bebas dan morfem terikat sedangkan dalam bI terdiri dua morfem bebas yang bergabung menjadi satu. Pada bagian lain, terlihat perbedaan pada jumlah dan gender. Pada jumlah pronomina refleksif pada bA menggunakan bentuk tunggal, dual dan jamak sedangkan pada bI mnggunakan bentuk tunggal dan jamak. Begitu juga dengan hal gender, dalam bA menggunakan bentuk maskulin, feminim dan netral sedangkan pada bI hanya menggunak bentuk netral. 
Tabel 7

Perbedaan pada Pronomina Posesiva

\begin{tabular}{|c|c|c|c|c|c|c|c|}
\hline \multicolumn{3}{|c|}{ BAHASA ARAB } & \multirow{2}{*}{ Glos } & \multicolumn{3}{|c|}{ BAHASA INGGRIS } & \multirow{2}{*}{ Glos } \\
\hline PP & Gender & Jumlah & & PP & Gender & Jumlah & \\
\hline$\{-\vec{\imath}\}$ & Netral & Tunggal & Punya saya & Mine & Netral & Tunggal & Punya Saya \\
\hline$\{-n \bar{a}\}$ & Netral & Jamak & Punya kita & Ours & Netral & \begin{tabular}{|c|} 
Jama \\
$\mathrm{k}$
\end{tabular} & Punya kita \\
\hline$\{-k a\}$ & Maskulin & Tunggal & Punya kamu lk & Yours & Netral & Tunggal & Punya kamu \\
\hline$\{-k i\}$ & Feminim & Tunggal & Punya kamu pr & Yours & Netral & Tunggal & Punya kamu \\
\hline$\{-k u m \bar{a}\}$ & Netral & Dual & $\begin{array}{c}\text { Punya kamu } 2 \\
\mathrm{lk} / \mathrm{pr}\end{array}$ & - & - & - & j r r \\
\hline$\{-k u m\}$ & Makulin & Jamak & Punya kalian lk & Yours & Netral & $\begin{array}{c}\text { Jama } \\
\mathrm{k}\end{array}$ & $\begin{array}{l}\text { Punya } \\
\text { kalian }\end{array}$ \\
\hline$(-h u\}$ & Maskulin & Tunggal & Punya dia $1 \mathrm{k}$ & His & Maskulin & Tunggal & Punya dia lk \\
\hline$\{-h \bar{a}\}$ & Feminim & Tunggal & Punya dia pr & hers & Feminim & Tunggal & Punya dia pr \\
\hline - & - & - & & Its & Netral & Tunggal & $\begin{array}{l}\text { Punya dia } \\
\text { (selain } \\
\text { manusia) }\end{array}$ \\
\hline$\{-h u m \bar{a}\}$ & Netral & Dual & $\begin{array}{c}\text { Punya dia } 2 \\
\mathrm{lk} / \mathrm{pr}\end{array}$ & - & - & - & 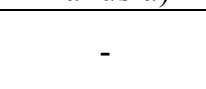 \\
\hline$\{-h u m\}$ & Maskulin & Tunggal & Punya mereka lk & Theirs & Netral & $\begin{array}{c}\text { Jama } \\
\mathrm{k}\end{array}$ & $\begin{array}{l}\text { Punya } \\
\text { mereka }\end{array}$ \\
\hline$\{-$ hunna $\}$ & Feminim & Jamak & $\begin{array}{c}\text { Punya mereka } \\
\text { pr }\end{array}$ & Theirs & Netral & $\begin{array}{c}\text { Jama } \\
\mathrm{k}\end{array}$ & $\begin{array}{l}\text { Punya } \\
\text { mereka }\end{array}$ \\
\hline
\end{tabular}

Dalam hal gender bA menggunakan bentuk feminim dan maskulin pada semua pronomina posesivanya baik itu pada jumlah tunggal, dual maupun jamak, sedangkan pada bI hanya menggunakan bentuk gender maskulin dan feminim hanya pada bentuk tunggal. Perbedaan lainnya terlihat pada bentuk jumlah, pada pronomina bA, penggunaan bentuk jumlah terdiri dari bentuk tunggal, dual dan jamak, sedangkan dalam bI hanya menggunakan bentuk tunggal dan jamak. Sedangkan dari sisi lain terlihat perbedaan pada jumlah pronomina, dalam bA pronomina posesiva berjumlah 11 buah pronomina sedangkan bI berjumlah 8 buah pronomina.
6. Perbedaan pada Pronomina Refleksif

Dalam bA, pronomina refleksif terdiri dari dua morfem yaitu moferm bebas dan morfem terikat sedangkan dalam bI terdiri dua morfem bebas yang bergabung menjadi satu. Pada bagian lain, terlihat perbedaan pada jumlah dan gender. Pada jumlah pronomina refleksif pada bA menggunakan bentuk tunggal, dual dan jamak sedangkan pada bI mnggunakan bentuk tunggal dan jamak. Begitu juga dengan hal gender, dalam bA menggunakan bentuk maskulin, feminim dan netral sedangkan pada bI hanya menggunak bentuk netral. 
Tabel 8

Perbedaan pada Pronomina Refleksif

\begin{tabular}{|c|c|c|c|c|c|}
\hline \multicolumn{3}{|c|}{ BAHASA ARAB } & \multicolumn{3}{|c|}{ BAHASA INGGRIS } \\
\hline PR & Gender & Jumlah & PR & Gender & Jumlah \\
\hline Nafsu $+\{-\vec{\imath}\}$ & Netral & Tunggal & Myself & Netral & Tunggal \\
\hline$N a f s u+\{-n \bar{a}\}$ & Netral & Jamak & Ourselves & Netral & Jamak \\
\hline Nafsu $+\{-k a\}$ & Maskulin & Tunggal & Youself & Netral & Tunggal \\
\hline$N a f s u+\{-k i\}$ & Feminim & Tunggal & Youself & Netral & Tunggal \\
\hline$N a f s u+\{-k u m \bar{a}\}$ & Netral & Dual & - & - & - \\
\hline Nafsu+\{-kum $\}$ & Maskulin & Jamak & Yourselves & Netral & Jamak \\
\hline Nafsu+(-hu\} & Maskulin & Tunggal & Himself & Maskulin & Tunggal \\
\hline$N a f s u+\{-h \bar{a}\}$ & Feminim & Tunggal & Herself & feminim & Tunggal \\
\hline- & - & - & Itself & Netral & Tunggal \\
\hline$N a f s u+\{-h u m \bar{a}\}$ & Netral & Dual & - & - & - \\
\hline Nafsu+\{-hum $\}$ & Maskulin & Tunggal & Themselves & netral & Jamak \\
\hline Nafsu+\{-hunna\} & Feminim & Jamak & Themselves & netral & Jamak \\
\hline
\end{tabular}

\section{PERSAMAAN PENANDA}

\section{GENDER ANTARA BAHASA ARAB DAN BAHASA INGGRIS}

Dalam analisis kontrastif, untuk mendapatkan hasil analisis yang tepat dan berimbang diperlukan sebuah analisa untuk mencari persamaan antara dua komponen yang diperbandingkan. Dalam hal ini, penulis memamparkan persamaan antara kedua bahasa. Berdasarkan data, persamaan pronomina antara kedua bahasa terdapat pada pronominal persona, demonstrativa, posesiva dan refleksif yang akan diuraikan secara berurutan.

\section{Persamaan pada Pronomina Persona}

Persamaan pronomina persona pada kedua bahasa terdapat pada pronominal persona pertama, kedua, dan ketiga. Akan tetapi pronomina persona kedua dan ketiga hanya terdapat pada bentuk morfem, yaitu menggunakan morfem bebas baik berperan sebagai subyek maupun obyek.

Pada pronomina persona pertama, kedua bahasa sama-sama menggunakan bentuk jumlah tunggal dan jamak, demikian juga dengan predikat gender, keduanya menggunakan jenis netrum.

Table 9

Persamaan pada Pronomina Persona

\begin{tabular}{|c|c|c|c|c|c|c|c|}
\cline { 3 - 7 } \multicolumn{2}{c|}{} & \multicolumn{3}{c|}{ BA } & \multicolumn{3}{c|}{ BI } \\
\cline { 2 - 7 } \multicolumn{2}{c|}{} & Tunggal & Jamak & Gender & Tunggal & Jamak & Gender \\
\hline \multirow{3}{*}{ Morfem Bebas } & Subyek & $\{$ Anā $\}$ & $\{$ Nahnu $\}$ & Netral & $\{I\}$ & $\{W e\}$ & Netral \\
\cline { 2 - 7 } & Obyek & $\{$ Iyyāya $\}$ & $\{$ Iyyāna $\}$ & Netral & $\{$ Me $\}$ & $\{$ Us $\}$ & Netral \\
\hline
\end{tabular}

2. Persamaan pada Pronomina Demosntrativa

Pronomina demonstrativa pada kedua bahasa menggunakan morfem bebas. Dalam jumlah dan jenis gender kedua bahasa sama-sama menggunakan jumlah tunggal dan berjenis netrum. 
Tabel 10

Persamaan pada Pronomina Demonstrativa

\begin{tabular}{|c|c|c|c|c|}
\hline \multirow{2}{*}{} & \multicolumn{2}{|c|}{ BA } & \multicolumn{2}{c|}{ BI } \\
\cline { 2 - 5 } & PD & Gender & PD & Gender \\
\hline \multirow{2}{*}{ Morfem bebas } & $\{$ Hunā $\}$ & $\{$ Netral $\}$ & $\{$ Here $\}$ & Netral \\
\cline { 2 - 5 } & $\{$ Hunā $k a\}$ & $\{$ Netral $\}$ & $\{$ There $\}$ & Netral \\
\hline
\end{tabular}

1. Persamaan pada Pronomina Posesiva Persamaan pada pronominal posesiva kedua bahasa terdapat pada jumlah dan jenis gender. Pronominal posesiva bA menggunakan bentuk tunggal dan jamak demikian juga dengan bI. Dalam hal jenis gender, kedua bahasa memiliki jenis gender netrum.

Table 11

Persamaan pada Pronomina Posesiva

\begin{tabular}{|c|c|c|c|c|c|c|c|}
\hline \multicolumn{3}{|c|}{ BAHASA ARAB } & \multirow{2}{*}{ Glos } & \multicolumn{3}{|c|}{ BAHASA INGGRIS } & \multirow{2}{*}{ Glos } \\
\hline PP & Gender & Jumlah & & PP & Gender & Jumlah & \\
\hline$\{-\bar{\imath}\}$ & Netral & Tunggal & Punya saya & Mine & Netral & Tunggal & Punya Saya \\
\hline$\{-n \bar{a}\}$ & Netral & Jamak & Punya kita & Ours & Netral & Jamak & Punya kita \\
\hline
\end{tabular}

2. Persamaan pada Pronomina Refleksif Pronomina refleksif baik bA maupun bI sama-sama menggunakan predikat gender netrum, pada sisi jumlah kedua bahasa menggunakan bentuk tunggal dan jamak.

Table 12

Persamaan pada Pronomina Refleksif

\begin{tabular}{|c|c|c|c|c|c|}
\hline \multicolumn{3}{|c|}{ BAHASA ARAB } & \multicolumn{3}{c|}{ BAHASA INGGRIS } \\
\hline PR & Gender & Jumlah & PR & Gender & Jumlah \\
\hline Nafsu $+\{-\overrightarrow{\boldsymbol{l}}\}$ & Netral & Tunggal & Myself & Netral & Tunggal \\
\hline $\boldsymbol{N a f s} \boldsymbol{u}+\{-\boldsymbol{n} \overline{\boldsymbol{a}}\}$ & Netral & Jamak & Ourselves & Netral & Jamak \\
\hline
\end{tabular}

\section{PENUTUP}

Penanda gender dalam persepektif bahasa sebenarnya tidak lepas dari unsur kultural karena bahasa merupakan cermin dari budaya yang melingkupinya. Penanda gender dalam bA didominasi oleh morfem terikat sedangkan sisanya berbentuk morfem bebas. Sedangkan bI didominasi oleh morfem bebas atau satuan leksikal.
Dari hasil analisis, pembagian gender tidak hanya terdapat dalam bA, akan tetapi juga terdapat dalam bI. Hal ini menunjukkan bahwa tidak hanya bA yang membagi atau memisahkan peranan gender akan tetapi bI juga demikian, hanya saja pembagian gender dalam bA lebih ketat dan komplek sebagaimana komplektisitas bahasa dan aturan gramatikanya. 
Luasnya obyek penelitian gender menjadikan penelitian ini seperti titik kecil dalam sebuah karya. Maka dari itu diperlukan penelitian yang lebih kompleks dan pengembangan yang lebih luas. Datadata yang ditampilkan penulis baru merupakan data mentah yang akan digunakan dalam keperluan penafsiran kultural dan sebagainya sehingga diperlukan penelitian lanjutan yang mengetengahkan hubungan antara bahasa dan kebudayaan.

\section{REFERENSI}

Anis, Ibrahim. at-Ta'nīs fi al-Lugah al'Arabiyyah. Kairo: Dār aț-Tibā'ah wa an-Nasyr wa at-Tauzīi ${ }^{\circ}, 1988$.

Anwar, Miftakhulkhairah. Penanda Gender dalam Perspektif Bahasa dan Budaya. Yogyakarta: Tesis UGM, 2004.

Echol, John M. Kamus Inggris Indonesia, Jakarta: Gramedia, 2005.

Ghulayani, Mustafa. Jāmi 'u ad-Durūs al'Arabiyah, Semarang: asy-Syifa, 1992.

Haryono, Rudi. ABC Plus English Grammar. Surabaya, Gitamedia Press, 2008.

Kridalaksana, Harimurti. Kamus Linguistik. Linguistik. Jakarta: Gramedia Pustaka Utama, 2008.

Ni'mah, Fuad. Mulakhoṣ Qawāidu alLugah al- 'Arabiyah. Beirut: Dār aśŚaqāfah al-Islāmiyah.

Manser, Martin H. Oxford Learner's Pocket Dictionary. New York: Oxford University Press, cetakan kelima, 1995.

Ma'luf, Louis. al-Munjid fi al-Lughah wa al-Ahkam Beirut: Maktabah asySyarkiyah, cetakan ke 40, 2003.

Munjin, "Ekspresi Bahasa dan Gender Sebuah Kajian Sosiolinguistik",
Jurnal Studi Gender dan Anak Yin

Yang, No. 2, Purwokerto: Juli

Desember 2008.

Muslikhati, Siti. Feminisme dan Pemberdayaan Perempuan dalam Timbangan Islam. Jakarta: Gema Insani Press, 2004.

Sudaryanto. Metode Linguistik. Yogyakarta: UGM Press, 1986.

Verhaar, J.W.M. Asas-asas Linguistik. Yogyakarta: UGM Press, 2001.

Yasin, Sulchan, Tinjauan Deskriptif Seputar Morfologi, Surabaya: Usaha Nasional, 1988. 